\title{
PERENCANAAN STRATEGIS TEKNOLOGI INFORMASI PADA PT ABC
}

\author{
Hoga Saragih ${ }^{1}$; Harta Pangestu ${ }^{2}$ \\ 1,2 Jurusan Teknik Informatika, Fakultas Ilmu Komputer, Universitas Bina Nusantara, \\ Jln. K.H. Syahdan No.9, Palmerah, Jakarta Barat 11480 \\ hogasaragih@gmail.com; hartapangestu@hotmail.com
}

\begin{abstract}
The aims of the research is to analyze business environment and IS/IT at the company, where the method used are interviews and observation in the company. With Balanced Score Card (BSC) and Critical Success Factor (CSF) tool, the real picture of the business environment could be obtained. Result of analysis of this research is an output in the form of IT division strategy i.e. target application needed to support business, technology and human resource to support the target application. From the resulting analysis, it can be conclude that existing business environment should be supported by target application, technology, and human resource to support business strategy.
\end{abstract}

Keywords: Balance Score Card (BSC), Critical Success Factor (CSF), strategy

\begin{abstract}
ABSTRAK
Tujuan dari penelitian ini adalah untuk menganalisis lingkungan bisnis dan IS/IT yang ada di perusahaan, di mana metode yang dipakai adalah dengan melalui wawancara dan observasi di perusahaan ini. Dengan alat bantu Balance Score Card (BSC) dan Critical Success Factor (CSF), maka didapatkan gambaran lingkungan bisnis yang sebenarnya. Hasil analisis dari penelitian ini merupakan keluaran berupa strategi divisi IT, yaitu aplikasi target yang dibutuhkan untuk mendukung bisnis, kebutuhan teknologi dan sumber daya manusia yang mendukung aplikasi target tersebut. Dari hasil analisis yang dilakukan, dapat disimpulkan bahwa lingkungan bisnis yang ada haruslah didukung oleh aplikasi target, teknologi, dan sumber daya manusia yang dihasilkan untuk mendukung strategi bisnis.
\end{abstract}

Kata kunci: Balance Score Card (BSC), Critical Success Factor (CSF), strategy

\section{PENDAHULUAN}

Balanced Score Card (BSC) merupakan salah satu metode pengukuran kinerja perusahaan secara keseluruhan yang menjabarkan visi dan strategi perusahaan ke dalam 4 perspektif, yaitu financial perspective, customer perspective, internal business process perspective, dan learning and growth perspective. Konsep BSC pertama kali dikembangkan oleh Robert S. Kaplan dan David P. Norton, di dalam buku yang berjudul "Translating Strategy into Action: The Balanced Score Card". Metode BSC melengkapi manajemen dengan framework yang mentranlasikan visi dan strategi ke dalam sistem pengukuran yang terintegrasi. Empat perspektif di dalam BSC menyatakan adanya saling keterkaitan untuk dapat menggambarkan strategi yang dimiliki perusahaan.

Keuntungan menggunakan BSC, yaitu (1) Dengan menggunakan 4 perspektif sebagai suatu kesatuan menjadikan senior manajemen dapat melihat unjuk kerja dari organisasi; (2) Jangka pendek, menengah dan panjang diatur seiring perjalanan dalam suatu kesatuan yang utuh; (3) Strategi tingkat atas dan menengah secara jelas terkoneksi dan dengan fokus yang benar; (4) Unjuk kerja hasil suatu organisasi berfokus pada hal hal yang penting agar dapat berkompetisi pada jangka panjang dan nilai nilai yang berguna untuk stakeholder. Sedangkan kerugian menggunakan BSC, yaitu (1) Pendekatan menggunakan BSC ini tidaklah dilakukan dalam waktu yang singkat dan memerlukan pemikiran yang cukup untuk menghasilkan BSC yang baik; (2) Keseluruhan implementasi dilakukan dalam waktu yang berkala dan tidak dapat dilakukan dalam waktu yang singkat.
CSF (Critical Success Factor) diperkenalkan oleh D. Ronald Daniel pada tahun 1960an, tetapi lebih dipopulerkan oleh Rockart (1979). Meskipun telah lama sejak diperkenalkannya CSF, konsep dan pendekatannya masih dianggap sangat baik untuk diterapkan pada bidang teknologi informasi. CSF dianggap penting karena membuat perusahaan untuk fokus pada kemampuan mereka untuk untuk mencapai kesuksesaan yang didefinisikan dalam CSF, dan juga memperlihatkan apakah perusahaan mempunyai kemampuan untuk mencapai CSF tersebut. CSF mengandung hal-hal yang merupakan kunci bagi keberhasilan visi dan misi perusahaan. Dengan demikian, kegiatan-kegiatan yang didefinisikan dalam CSF haruslah secara konsisten dilakukan atau dipenuhi jika perusahaan ingin mencapai tujuan yang diinginkan, yaitu visi misinya. Ketika seorang pemimpin dalam suatu perusahaan telah mendefinisikan goal nya (visi misi), maka pemimpin tersebut juga harus sudah memikirkan apa yang harus dilakukan untuk dapat mencapai goal nya.

Pengunaan kata CSF pada awal mulanya digunakan pada lingkungan analisis data dan bisnis. Dikarenakan defini dari CSF ini sangatlah penting untuk menentukan keberhasilan akan suatu perusahaan/usaha, maka diperlukannya suatu standar/ukuran sebagai indikasi apakah kegiatan atau langkah langkah yang ada sekarang dan juga kegiatan yang akan datang sudah memenuhi kriteria dari sukses yang telah didefinisikan terlebih dahulu, sebagai target yang akan dicapai. Indikasi ini dinamakan dengan Key Performance Indicator (KPI). Permasalahan yang ada secara garis besar adalah (1) Kemampuan bersaing kurang (order dilakukan dengan cara manual (melalui email dalam bentuk excel file/scan ataupun 
fax); (2) Software pendukung bisnis sistem saat ini begitu banyak kekurangan untuk mendukung operasional.

\section{METODE PENELITIAN}

Untuk mendapatkan IT Strategy Planning yang baik, beberapa langkah persiapan perlu dilakukan. Hal yang paling mendasar adalah memahami keadaan lingkungan bisnis dan IS/IT yang ada. Kemudian, dibandingkan dengan apa yang dibutuhkan oleh pihak bisnis, dimulai dari visi misi dan diturunkan sampai ke masing masing bagian agar dapat mencapai tujuan besarnya, yaitu visi dan misi sehingga didapatkannya IT Strategy Planning yang dapat mendukung dan sejalan dengan bisnis. Aplikasi maupun teknologi yang dibutuhkan yang paling utama bukanlah aplikasi/teknologi yang paling terdepan/terbaru/tercanggih, tetapi IT Strategy Planning diharapkan dapat memberikan solusi IS maupun IT yang tepat.

Metode yang dipergunakan dalam penulisan ini terbagi menjadi 3 bagian. Pertama, analisis kebutuhan bisnis dan kondisi IS/IT, terdiri dari analisis kebutuhan bisnis (BSC), analisis strategi divisi untuk support kebutuhan bisnis (CSF), dan analisis kondisi IS/IT. Kedua, pendefinisian target aplikasi, terdiri dari pendefinisian kemungkinan aplikasi, pendefinisian target aplikasi, dan Pendefinisian dan pemilihan strategi. Ketiga, identifikasi strategi dan pemilihan sistem informasi, terdiri dari strategi teknologi informasi dan strategi manajemen sumber daya manusia. Berikut ini merupakan penjelasan dari masing masing bagian metode tersebut.

\section{HASIL DAN PEMBAHASAN}

\section{Analisis Kebutuhan Bisnis (BSC) dan Kondisi IS/IT}

Perencanaan strategi yang dihasilkan haruslah berasal dari kebutuhan bisnis. Dengan demikian, langkah awal dalam penelitian ini adalah mendapatkan gambaran yang jelas mengenai kebutuhan bisnis yang ada di perusahaan. Pendekatan yang dilakukan untuk mengetahui kebutuhan bisnis yang ada adalah dengan menggunakan metode BSC. Setelah didapatkan BSC roadmap (Gambar 1), masing-masing point dari BSC ini akan 'diturunkan' menjadi masing-masing divisi yang dapat mendukung keberhasilan dari BSC tersebut dengan menggunakan CSF. Selain daripada itu, kondisi IS/IT yang ada menjadi suatu acuan mengenai aplikasi, teknologi dan sumber daya manusia apa lagi yang diperlukan untuk menunjang BSC dan CSF yang telah dihasilkan tersebut. Beberapa hal yang diperlukan dalam fase ini adalah visi dan misi perusahaan, lingkungan bisnis (BSC), lingkungan masing-masing divisi serta kondisi IS/IT.

\section{Pendefinisian Target Aplikasi}

Setelah memahami kebutuhan dari bisnis, dari segi visi misi dan strategi perusahaan yang akan datang dan juga dari keadaan IS/IT yang ada saat ini, langkah berikutnya adalah bagaimana IS/IT dapat mendukung kebutuhan bisnis tersebut. Setelah CSF dari masing-masing bagian telah didefinisikan, maka gambaran yang jelas mengenai faktor keberhasilan dari masing-masing bagian tersebut haruslah didukung/ support oleh IS. Aplikasi-aplikasi yang kemungkinan dapat membantu factor-faktor keberhasilan tersebut diuraikan. Nantinya yang akan dipilih adalah aplikasi terbaik untuk mendukung keberhasilan dari masing-masing bagian.

Setelah dilakukannya IS opportunities, maka aplikasiaplikasi yang berhubungan dijadikan satu kesatuan yang dinamakan dengan Target Applications sehingga di dalam Target Applications tersebut terdapat sekumpulan aplikasiaplikasi yang berhubungan, di mana user cukup 'memanggil' Target Applications tersebut untuk memakai aplikasi-aplikasi

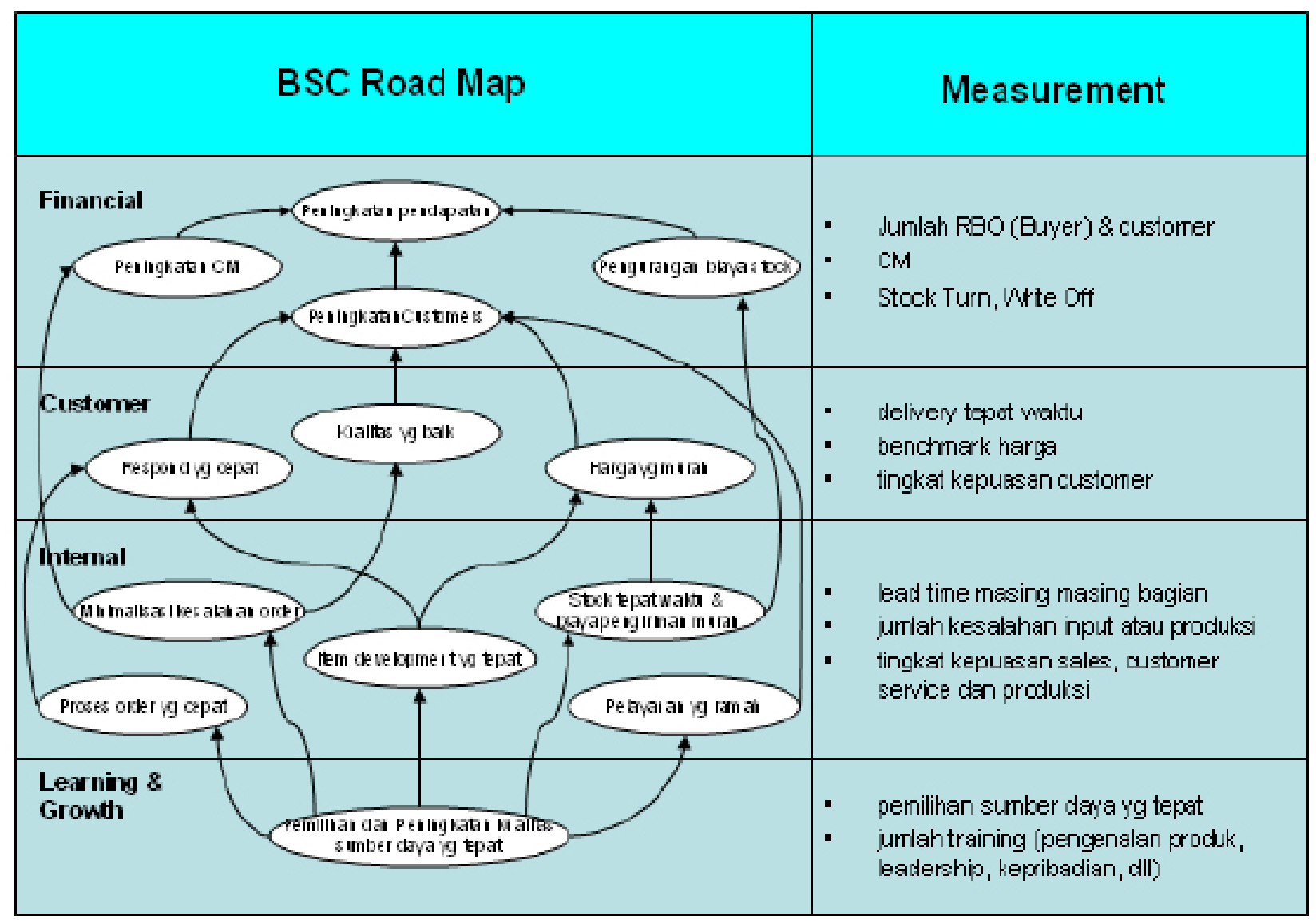

Gambar 1 BSC Road Map 
yang sejenis. Di dalam fase ini, juga diberikan bobot Target Applications yang mana yang merupakan prioritas.

\section{Identifikasi Strategi dan Pemilihan Sistem Informasi}

Pada fase ini, pemilihan dari beberapa Target Applications yang telah dibobotkan dan juga pertimbangan dari beberapa hal seperti dari segi biaya dan proses apa yang akan diambil (mengubah/menambahkan fitur-fitur dari program yang sekarang ada, membeli paket software yang baru dan lain lain). Teknik implementasi yang dapat digunakan, yaitu software reengineering (mengubah/ menambahkan fitur dari modul aplikasi yang ada saat ini), package software development (membeli aplikasi yang siap pakai), end user development (membuat baru aplikasi dari internal staf), dan mixed software development (kombinasi dari ketiga point di atas).

Target aplikasi yang telah ditentukan pada fase sebelumnya membutuhkan teknologi yang mendukung pula, baik dari segi hardware, networking, dan platform. Pada fase ini, kebutuhan teknologi dari masing-masing aplikasi dicatat dan dibandingkan dengan teknologi yang ada sehingga kebutuhan teknologi yang memang belum ada dapat diketahui. Selain daripada teknologi yang dibutuhkan oleh sebuah target aplikasi untuk berhasil diimplementasikan, sumber daya manusia merupakan hal yang tidak kalah pentingnya. Sumber daya manusia yang dibutuhkan oleh suatu aplikasi dicatat dan dibandingkan dengan sumber daya manusia yang ada sehingga kebutuhan akan sumber daya manusia dapat diketahui kekurangannya serta dapat dicarikan solusinya seperti merekrut karyawan baru atau mutasi karyawan dari bagian lain yang memang sesuai dengan kriteria yang dibutuhkan.

Pertama, perspektif finansial. Strategi utama dari perspektif finansial adalah peningkatan pendapatan. Untuk meningkatkan pendapatan, dapat dilakukan dengan meningkatkan penghasilan yang masuk, mengurangi biaya yang keluar ataupun keduanya. Biaya SG \& A yang keluar seperti biaya travelling, telpon, listrik, dan lain-lain, sedangkan biaya stock/inventory juga merupakan hal yang penting dikarenakan cash flow menjadi terhambat dengan adanya uang yang 'tidak bergerak' berupa stok di gudang. Lain halnya dengan stok yang dipakai untuk keperluan produksi ataupun penjualan ke kustomer. Kedua, perspektif kustomer. Pada umumnya, di hampir semua sektor industri, baik itu manufaktur maupun trading, ada 3 hal dasar yang diinginkan oleh kustomer, yaitu respon yang cepat, kualitas yang baik, dan harga yang murah. Ketiga, perspektif internal. Untuk mendukung keberhasilan dari perspektif kustomer, beberapa hal dukungan utama dari internal adalah proses order yg cepat, stok tepat waktu, minimalisasi kesalahan order, dan item development yang cepat. Keempat, perspektif learning and growth. Sumber daya manusia merupakan inti dari keberhasilan suatu proses. Tanpa adanya sumber daya yang tepat, maka keberhasilan dari suatu standar proses yang diinginkan sulit atau bahkan tidak dapat dicapai.

\section{Analisis Kebutuhan Bisnis (Critical Success Factor)}

Di dalam analisis ini, terdapat 5 jenis divisi, yaitu (1) Divisi Customer Service - Critical Success Factors (Tabe 1), (2) Divisi Produksi - Critical Success Factors (Tabel 2), (3) Divisi Product Development - Critical Success Factors (Tabel 3), (4) Divisi Pembelian - Critical Success Factors (Tabel 4), (5) Divisi Human Resource - Critical Success Factors (Tabel 5).
Tabel 1 CSF Customer Service

\begin{tabular}{|c|c|c|}
\hline No & CSF & KPI \\
\hline \multirow[t]{5}{*}{1} & $\begin{array}{l}\text { Respond order yang } \\
\text { cepat }\end{array}$ & Proses order: \\
\hline & & Lead time offset $=7$ hari \\
\hline & & Lead time printed label $=5$ hari \\
\hline & & Lead time printed woven $=5$ hari \\
\hline & & $\begin{array}{l}\text { Umpan balik ke kustomer jika tidak dapat } \\
\text { terpenuhi }<=24 \text { jam }\end{array}$ \\
\hline 2 & $\begin{array}{l}\text { Minimalisasi } \\
\text { kesalahan order }\end{array}$ & Defect rate $<1 \%$ \\
\hline 3 & $\begin{array}{l}\text { Pelayanan yang } \\
\text { ramah }\end{array}$ & Survei kepuasan kustomer nilainya 4 of 5 \\
\hline
\end{tabular}

Tabel 2 CSF Produksi

\begin{tabular}{ccl}
\hline No & \multicolumn{1}{c}{ CSF } & \multicolumn{1}{c}{ KPI } \\
\hline 1 & Proses order yang cepat & Proses order: \\
& & Lead time offset $=7$ hari \\
& & Lead time printed label $=$ \\
& & 5 hari \\
& & Lead time printed woven $=$ \\
& & 5 hari \\
2 & Minimalisasi kesalahan & Defect rate $<1 \%$ \\
\hline
\end{tabular}

Tabel 3 CSF Product Development

\begin{tabular}{ccl}
\hline No & \multicolumn{1}{c}{ CSF } & \multicolumn{1}{c}{ KPI } \\
\hline 1 & Item development yang cepat & Lead time $=3$ hari \\
& Harga material murah & $\begin{array}{l}\text { Harga termurah dari minimum } \\
\text { 3 supplier }\end{array}$ \\
& &
\end{tabular}

Tabel 4 CSF Pembelian

\begin{tabular}{cll}
\hline No & \multicolumn{1}{c}{ CSF } & \multicolumn{1}{c}{ KPI } \\
\hline 1 & $\begin{array}{l}\text { Proses purchase order requisition } \\
\text { dengan cepat }\end{array}$ & $\begin{array}{l}\text { Purchase order requisition } \\
\text { diproses dalam waktu 1x24 Jam } \\
\text { berkontribusi terhadap kenaikan }\end{array}$ \\
2 & Biaya pengiriman murah & CM
\end{tabular}

Tabel 5 CSF Human Resource

\begin{tabular}{cll}
\hline No & \multicolumn{1}{c}{ CSF } & \multicolumn{1}{c}{ KPI } \\
\hline 1 & $\begin{array}{l}\text { Pemilihan sumber daya yang } \\
\text { tepat }\end{array}$ & $\begin{array}{l}\text { Calon karyawan lulus masa } \\
\text { percobaan }>95 \%\end{array}$ \\
2 & $\begin{array}{l}\text { Peningkatan kualitas sumber } \\
\text { daya }\end{array}$ & $\begin{array}{l}\text { Jumlah dan Jenis training yang } \\
\text { diadakan memenuhi target yg telah } \\
\text { ditetapkan }\end{array}$ \\
3 & Turn over karyawan rendah & $\begin{array}{l}\text { Persentase turn over }<5 \% \\
\text { Survei kepuasan karyawan nilainya } \\
4 \text { of } 5\end{array}$ \\
\hline
\end{tabular}

\section{Target Aplikasi}

Terdapat 6 jenis target aplikasi, yaitu application target customer service, application target produksi, application target produk development, application target pembelian, application target human resource, application target it (Tabel $6-11$ ), dan target application portfolio (Gambar 2). 


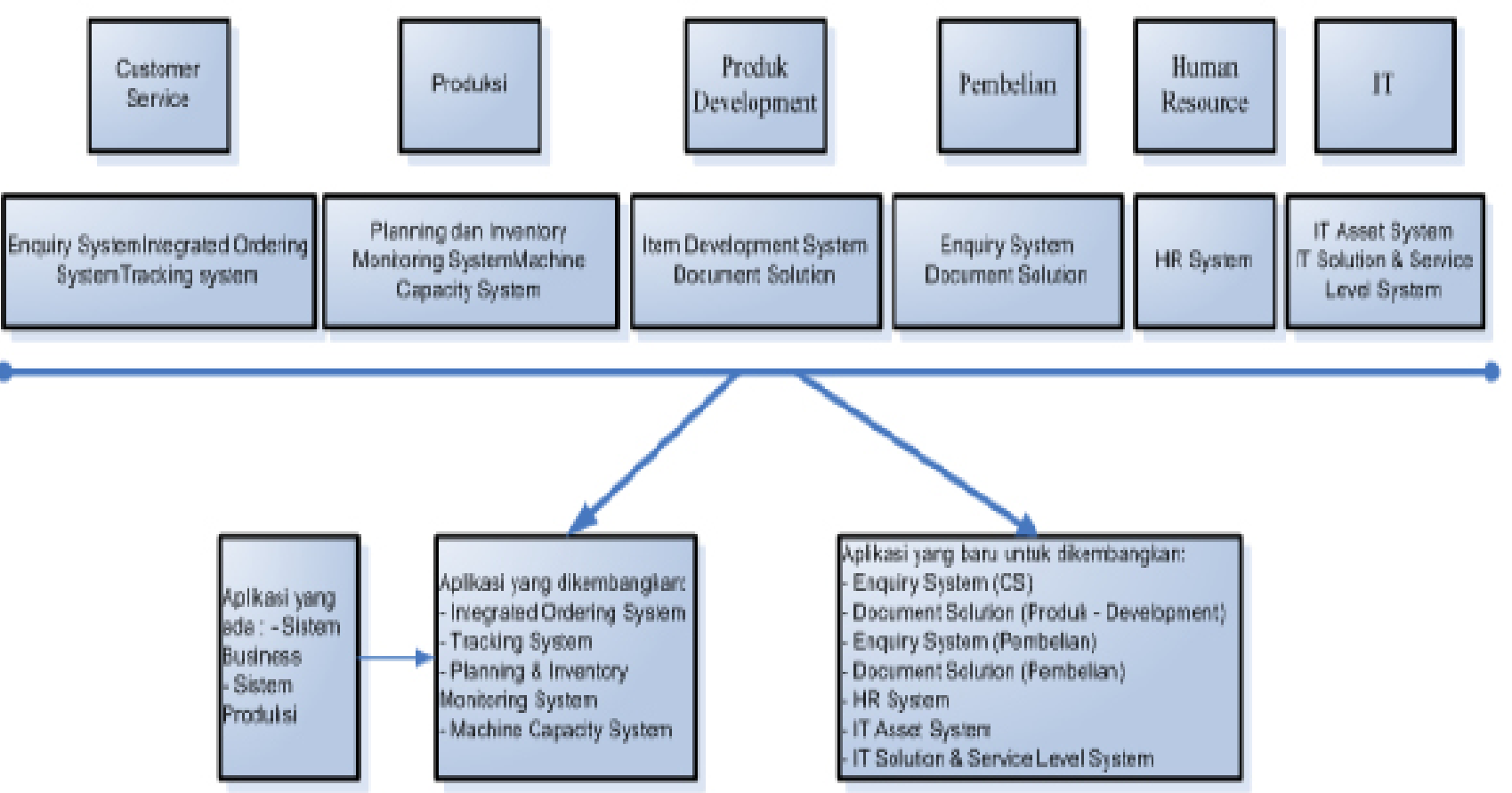

Gambar 2 Target Application Portfolio

Tabel 6 Application Target Customer Service

\begin{tabular}{cll}
\hline Business Process & \multicolumn{1}{c}{ IS Opportunities } & \multicolumn{1}{c}{$\begin{array}{c}\text { Target } \\
\text { Application }\end{array}$} \\
\hline Customer Service & Log enquiry system & Enquiry System \\
& EDI, Web Order & Integrated \\
& EDI/Web Order link ke Sistem & Ordering \\
& Produksi dan Sistem Bisnis & System \\
& Tracking order & Tracking \\
& & system \\
\hline
\end{tabular}

Tabel 7 Application Target Produksi

\begin{tabular}{|c|c|c|}
\hline $\begin{array}{c}\text { Business } \\
\text { Process }\end{array}$ & IS Opportunities & $\begin{array}{c}\text { Target } \\
\text { Application }\end{array}$ \\
\hline Produksi & $\begin{array}{l}\text { automatic alert min inventory } \\
\text { visibility order pada tahap } \\
\text { awal } \\
\text { alert late order ETA } \\
\text { Bill of Material } \\
\text { Scheduling order } \\
\text { automatic alert late schedule } \\
\text { to CS }\end{array}$ & $\begin{array}{l}\text { Planning dan } \\
\text { Inventory } \\
\text { Monitoring } \\
\text { System }\end{array}$ \\
\hline & $\begin{array}{l}\text { kapasitas mesin } \\
\text { Log maintainance mesin } \\
\text { Log waktu mesin bekerja }\end{array}$ & $\begin{array}{l}\text { Machine Capacity } \\
\text { System }\end{array}$ \\
\hline
\end{tabular}

Tabel 8 Application Target Produk Development

\begin{tabular}{clc}
\hline Business Process & \multicolumn{1}{c}{ IS Opportunities } & Target Application \\
\hline Produk Development & $\begin{array}{l}\text { Web status item } \\
\text { development } \\
\text { automatic alert perubahan } \\
\text { status item development }\end{array}$ & $\begin{array}{c}\text { Item Development } \\
\text { to Sales, CS }\end{array}$ \\
& Costem \\
& sistem dokumen & Document Solution \\
& &
\end{tabular}

Tabel 9 Application Target Pembelian

\begin{tabular}{cll}
\hline Business Process & \multicolumn{1}{c}{ IS Opportunities } & \multicolumn{1}{c}{ Target Application } \\
\hline Pembelian & Log requisition system & Enquiry System \\
& sistem dokumen & Document Solution \\
\hline
\end{tabular}

Tabel 10 Application Target Human Resource

\begin{tabular}{ccc}
\hline $\begin{array}{c}\text { Business } \\
\text { Process }\end{array}$ & IS Opportunities & Target Application \\
\hline $\begin{array}{c}\text { Human } \\
\text { Resource }\end{array}$ & Candidate profile sistem & HR System \\
\hline
\end{tabular}

Tabel 11 Application Target IT

\begin{tabular}{clc}
\hline $\begin{array}{c}\text { Business } \\
\text { Process }\end{array}$ & IS Opportunities & Target Application \\
\hline IT & $\begin{array}{l}\text { Hardware/software } \\
\text { inventory system } \\
\text { automatic alert system } \\
\text { fail }\end{array}$ & IT Asset System \\
& Help desk system & IT Solution \& Service \\
& Log enquiry system & Level System \\
& Knowledge base & \\
\hline
\end{tabular}

Tabel 12 Pembobotan Target Aplikasi

\begin{tabular}{ccc}
\hline Pembobotan & Keterangan & Bobot \\
\hline VH & Very High & 5 \\
H & High & 4 \\
M & Moderate & 3
\end{tabular}




\begin{tabular}{ccc} 
L & Low & 2 \\
VL & Very Low & 1 \\
\hline
\end{tabular}

Tabel 13 Pembobotan CSF dan Target Aplikasi Customer Service

\begin{tabular}{lccc}
\hline \multicolumn{1}{c}{ CSF } & $\begin{array}{c}\text { Respond } \\
\text { Order yang } \\
\text { Cepat }\end{array}$ & $\begin{array}{c}\text { Minimalisasi } \\
\text { Kesalahan } \\
\text { Order }\end{array}$ & Average \\
\hline Enquiry System & 3 & 1 & 2 \\
Integrated Ordering & 5 & 5 & 5 \\
System & 5 & 2 & 3.5 \\
Tracking system & & & \\
\hline
\end{tabular}

Tabel 14 Pembobotan CSF dan Target Aplikasi Produksi

\begin{tabular}{cccc}
\hline CSF & $\begin{array}{c}\text { Proses } \\
\text { Order } \\
\text { yang } \\
\text { Cepat }\end{array}$ & $\begin{array}{c}\text { Minimalisasi } \\
\text { Kesalahan } \\
\text { Order }\end{array}$ & Average \\
\hline
\end{tabular}

\section{Divisi Produksi}

Planning and Inventory

Monitoring System

Machine Capacity

System

\begin{tabular}{lll}
5 & 3 & 4 \\
4 & 1 & 2.5 \\
\hline
\end{tabular}

Tabel 15 Pembobotan CSF dan Target Aplikasi Produk Development

\begin{tabular}{|c|c|c|c|}
\hline $\begin{array}{c}\text { CSF } \\
\text { Target Aplikasi }\end{array}$ & $\begin{array}{c}\text { Item } \\
\text { Development } \\
\text { yang Cepat }\end{array}$ & $\begin{array}{c}\text { Harga } \\
\text { Material } \\
\text { Murah }\end{array}$ & Average \\
\hline Item Development System & 5 & 3 & 4 \\
\hline Document Solution & 4 & 1 & 2.5 \\
\hline
\end{tabular}

Tabel 16 Pembobotan CSF dan Target Aplikasi Pembelian

\begin{tabular}{lccc}
\hline $\begin{array}{c}\text { CSF } \\
\text { Target Aplikasi }\end{array}$ & $\begin{array}{c}\text { Proses } \\
\text { Purchase Order } \\
\text { Requisition } \\
\text { Dengan Cepat }\end{array}$ & $\begin{array}{c}\text { Biaya } \\
\text { Pengiriman } \\
\text { Murah }\end{array}$ & Average \\
\hline Enquiry System & 4 & 4 & 4 \\
Document Solution & 4 & 2 & 3 \\
\hline
\end{tabular}

Tabel 17 Pembobotan CSF dan Target Aplikasi Human Resource

\begin{tabular}{cccccc}
\hline $\begin{array}{c}\text { CSF } \\
\text { Target } \\
\text { Aplikasi }\end{array}$ & $\begin{array}{c}\text { Pemilihan } \\
\text { Sumber } \\
\text { Daya } \\
\text { yang } \\
\text { Tepat }\end{array}$ & $\begin{array}{c}\text { Peningkatan } \\
\text { Kualitas } \\
\text { Sumber } \\
\text { Daya }\end{array}$ & $\begin{array}{c}\text { Turn Over } \\
\text { Karyawan } \\
\text { Rendah }\end{array}$ & $\begin{array}{c}\text { Kepuasan } \\
\text { Karyawan } \\
\text { Tinggi }\end{array}$ & Average \\
\hline $\begin{array}{c}\text { HR } \\
\text { System }\end{array}$ & 5 & 5 & 5 & 5 & 5 \\
\hline
\end{tabular}

Tabel 18 Pembobotan CSF dan Target Aplikasi IT

\begin{tabular}{lccc}
\hline $\begin{array}{c}\text { CSF } \\
\text { Target Aplikasi }\end{array}$ & $\begin{array}{c}\text { SLA } \\
\text { yang Tinggi }\end{array}$ & $\begin{array}{c}\text { Maintain Asset IT } \\
\text { Dengan Baik }\end{array}$ & Average \\
\hline IT Asset System & 2 & 4 & 3 \\
$\begin{array}{l}\text { IT Solution \& } \\
\begin{array}{l}\text { Service Level } \\
\text { System }\end{array}\end{array}$ & 5 & 1 & 3 \\
\hline
\end{tabular}

Tabel 19 Metode Implementasi

\begin{tabular}{|c|c|c|c|c|}
\hline \multirow[b]{2}{*}{ Target Aplikasi } & \multicolumn{4}{|c|}{ Metode Implementasi } \\
\hline & $\begin{array}{c}\text { Software } \\
\text { Reengineering }\end{array}$ & $\begin{array}{l}\text { Package } \\
\text { Software }\end{array}$ & $\begin{array}{c}\text { End User } \\
\text { Development }\end{array}$ & Custom Software Development \\
\hline \multicolumn{5}{|l|}{ Customer Service } \\
\hline Enquiry System & & $\mathrm{X}$ & $\mathrm{X}$ & \multirow{3}{*}{$\mathrm{X}$} \\
\hline Integrated Ordering System & & & & \\
\hline Tracking system & $\mathrm{X}$ & & & \\
\hline \multicolumn{5}{|l|}{ Produksi } \\
\hline Planning \& Inventory Monitoring System & $\mathrm{X}$ & & & \\
\hline Machine Capacity System & $\mathrm{X}$ & $\mathrm{X}$ & & \\
\hline \multicolumn{5}{|l|}{ Produk Development } \\
\hline Item Development System & & & $\mathrm{X}$ & \\
\hline Document Solution & & $\mathrm{X}$ & $\mathrm{X}$ & \\
\hline \multicolumn{5}{|l|}{ Pembelian } \\
\hline Enquiry System & & $\mathrm{X}$ & $\mathrm{X}$ & \\
\hline Document Solution & & $\mathrm{X}$ & $\mathrm{X}$ & \\
\hline \multicolumn{5}{|l|}{ Human Resource } \\
\hline HR System & & $\mathrm{X}$ & $\mathrm{X}$ & \\
\hline \multicolumn{5}{|l|}{ IT } \\
\hline IT Asset System & & $\mathrm{X}$ & $\mathrm{X}$ & \\
\hline IT Solution \& Service Level System & & $\mathrm{X}$ & $\mathrm{X}$ & \\
\hline
\end{tabular}


Tabel 20 Target Aplikasi versus Data Pendukung

\begin{tabular}{|c|c|c|c|c|c|c|}
\hline & Metode Implementasi & Biaya & $\begin{array}{c}\text { Tingkat } \\
\text { Customisasi }\end{array}$ & $\begin{array}{l}\text { Tingkat Kecocokan } \\
\text { dgn End User }\end{array}$ & Waktu & Project Size \\
\hline \multirow[t]{2}{*}{ Enquiry System (CS) } & End User Development & 18 & Tinggi & Tinggi & Lama & Kecil \\
\hline & Package Software & 15.75 & Rendah & Rendah & Singkat & Kecil \\
\hline Integrated Ordering System & $\begin{array}{l}\text { Custom Software } \\
\text { Development }\end{array}$ & 94.5 & Tinggi & Tinggi & Lama & Besar \\
\hline Tracking system & Software Reengineering & 14 & Tinggi & Tinggi & Lama & Kecil \\
\hline $\begin{array}{l}\text { Planning dan Inventory } \\
\text { Monitoring System }\end{array}$ & Software Reengineering & 39 & Tinggi & Tinggi & Lama & Sedang \\
\hline \multirow[t]{2}{*}{ Machine Capacity System } & Software Reengineering & 20 & Tinggi & Tinggi & Lama & Kecil \\
\hline & Package Software & 18.9 & Rendah & Rendah & Singkat & Kecil \\
\hline Item Development System & End User Development & 17 & Tinggi & Tinggi & Lama & Kecil \\
\hline \multirow[t]{2}{*}{ Enquiry System (Pembelian) } & End User Development & 18 & Tinggi & Tinggi & Lama & Kecil \\
\hline & Package Software & 15.75 & Rendah & Rendah & Singkat & Kecil \\
\hline \multirow[t]{2}{*}{ Document Solution } & Package Software & 10.5 & Rendah & Rendah & Singkat & Kecil \\
\hline & End User Development & 16 & Tinggi & Tinggi & Lama & Kecil \\
\hline \multirow[t]{2}{*}{ HR System } & Package Software & 42 & Rendah & Rendah & Singkat & Sedang \\
\hline & End User Development & 61 & Tinggi & Tinggi & Lama & Sedang \\
\hline \multirow[t]{2}{*}{ IT Asset System } & End User Development & 15 & Tinggi & Tinggi & Lama & Kecil \\
\hline & Package Software & 11 & Rendah & Rendah & Singkat & Kecil \\
\hline \multirow[t]{2}{*}{$\begin{array}{l}\text { IT Solution \& Service Level } \\
\text { System }\end{array}$} & End User Development & 22 & Tinggi & Tinggi & Lama & Kecil \\
\hline & Package Software & 15.75 & Rendah & Rendah & Singkat & Kecil \\
\hline
\end{tabular}

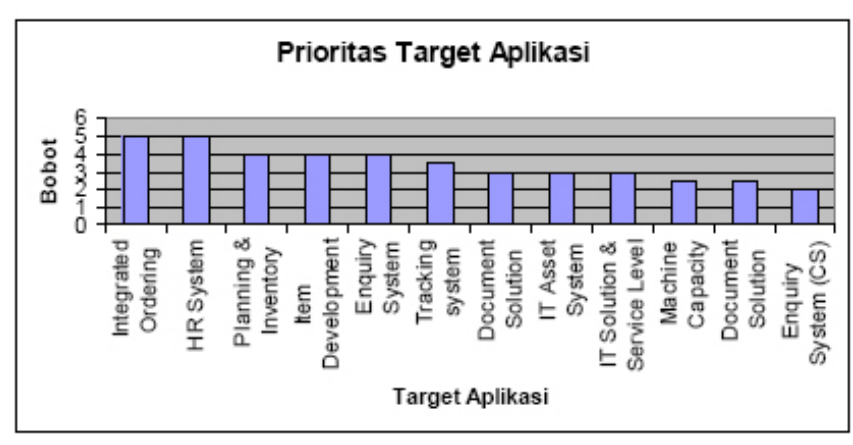

Gambar 3 Prioritas Target Aplikasi

Grafik 1 Estimasi Biaya yang Dibutuhkan

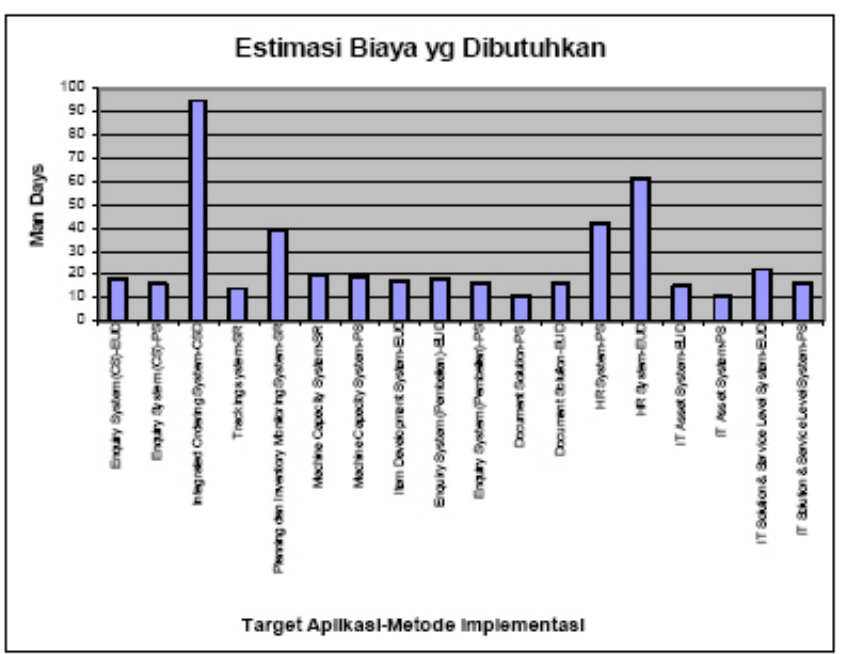

\section{Strategi Teknologi Informasi}

Target aplikasi yang akan dikembangkan membutuhkan teknologi untuk mendukungnya.

Grafik 2 Target Aplikasi dan Biaya

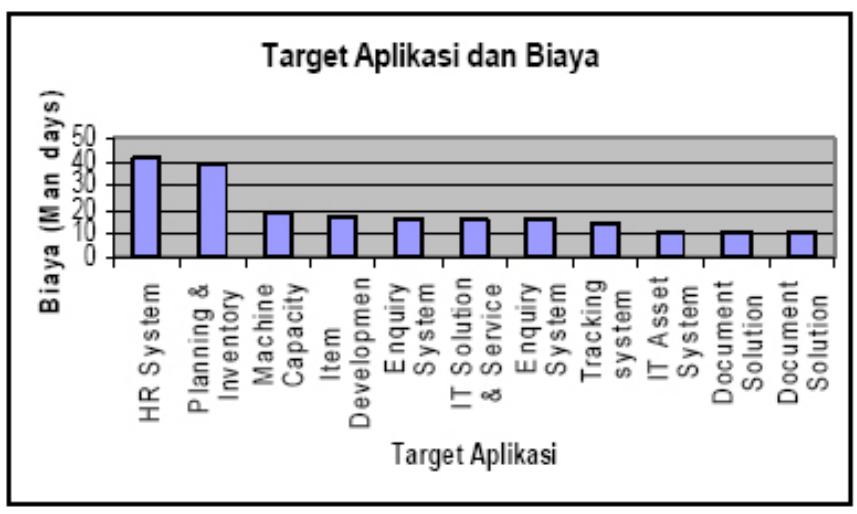

Jika teknologi yang dibutuhkan belum tersedia, maka teknologi tersebut harus direncanakan juga agar dapat mendukung kebutuhan target aplikasi. 
Tabel 21 Target Teknologi

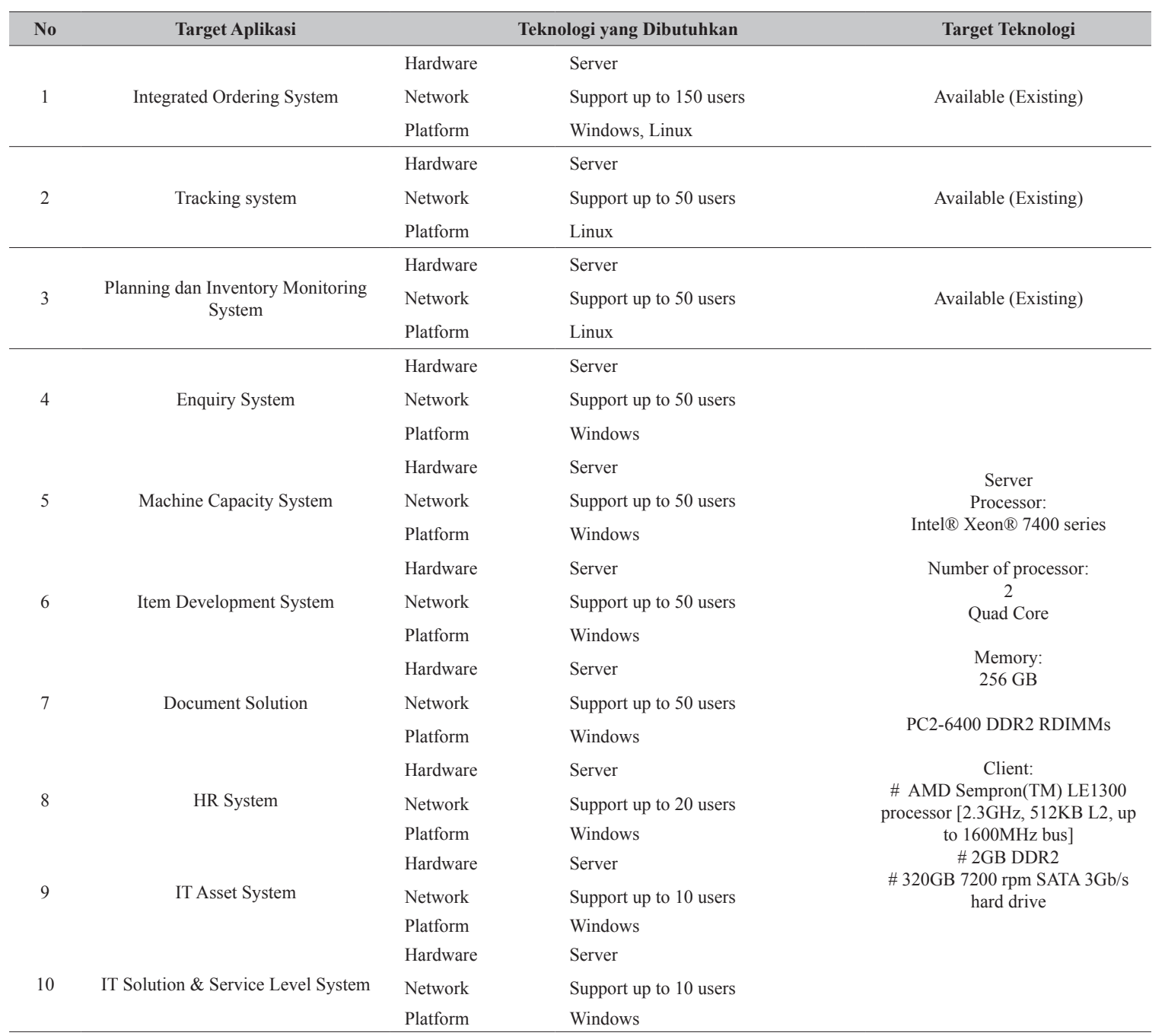

\section{Strategi Manajemen Sumber Daya}

\section{Manusia}

Tabel 22 Target Sumber Daya Manusia

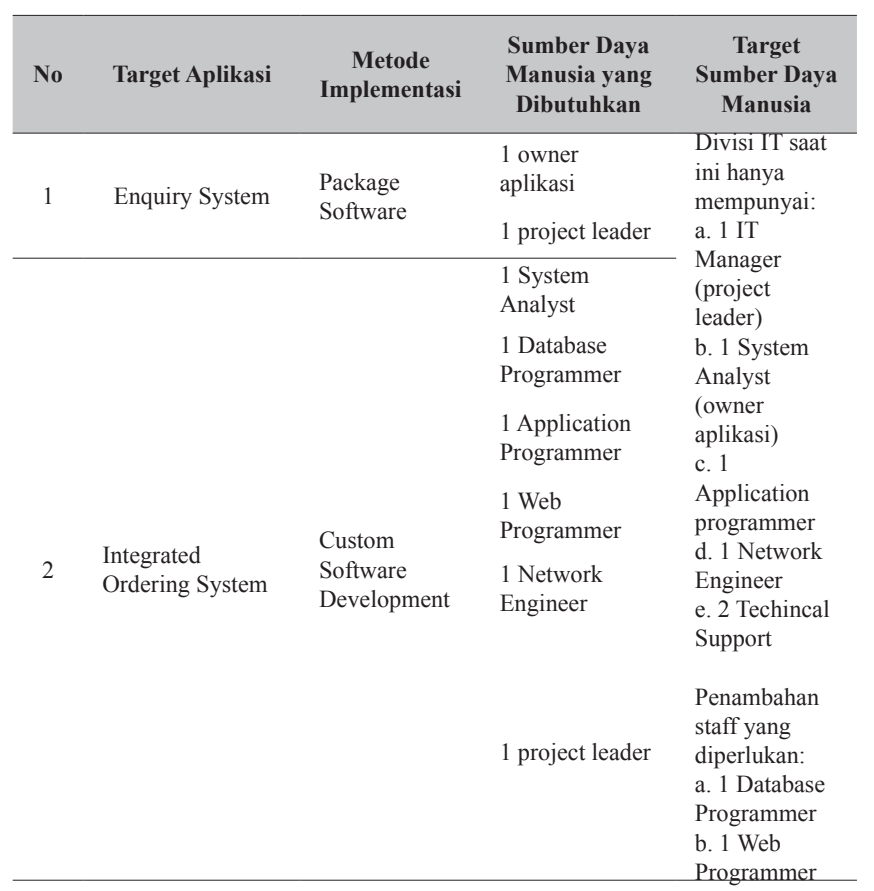

1 System Analyst

1 Database

Programmer

Software 1 Application

$\begin{array}{ll}\text { Reengineering } & 1 \text { Application } \\ & \text { Programmer }\end{array}$

1 Network Engineer

1 project leader

1 System Analyst

1 Database

Programmer

Planning dan

4 Inventory

System

Software

1 Application

Programmer

1 Network Engineer

1 project leader

\begin{tabular}{|c|c|c|c|}
\hline & & & 1 project leader \\
\hline \multirow{2}{*}{5} & \multirow{2}{*}{$\begin{array}{l}\text { Machine Capacity } \\
\text { System }\end{array}$} & \multirow{2}{*}{$\begin{array}{l}\text { Package } \\
\text { Software }\end{array}$} & 1 owner aplikasi \\
\hline & & & 1 project leader \\
\hline \multirow{6}{*}{6} & \multirow{6}{*}{$\begin{array}{l}\text { Item Development } \\
\text { System }\end{array}$} & \multirow{6}{*}{$\begin{array}{l}\text { End User } \\
\text { Development }\end{array}$} & 1 System Analyst \\
\hline & & & 1 Database \\
\hline & & & Programmer \\
\hline & & & 1 Web Programmer \\
\hline & & & 1 Network Engineer \\
\hline & & & 1 project leader \\
\hline
\end{tabular}




\begin{tabular}{clll}
\hline 7 & $\begin{array}{l}\text { Document } \\
\text { Solution }\end{array}$ & $\begin{array}{l}\text { Package } \\
\text { Software }\end{array}$ & $\begin{array}{l}1 \text { owner aplikasi } \\
1 \text { project leader }\end{array}$ \\
\hline 8 & HR System & $\begin{array}{l}\text { Package } \\
\text { Software }\end{array}$ & $\begin{array}{l}1 \text { owner aplikasi } \\
1 \text { project leader }\end{array}$ \\
\hline \multirow{2}{*}{9} & IT Asset System & $\begin{array}{l}\text { Package } \\
\text { Software }\end{array}$ & $\begin{array}{l}1 \text { owner aplikasi } \\
1 \text { project leader }\end{array}$ \\
\hline \multirow{2}{*}{10} & $\begin{array}{l}\text { IT Solution \& } \\
\text { Service Level } \\
\text { System }\end{array}$ & $\begin{array}{l}\text { Package } \\
\text { Software }\end{array}$ & 1 owner aplikasi \\
1 project leader
\end{tabular}

\section{SIMPULAN}

Berdasarkan hasil analisis bisnis yang ada di perusahaan melalui alat bantu BSC (Balance Score Card) dan CSF (Critical Success Factor), didapatkan hasil yang dapat memperjelas arah yang ingin dituju dari perusahaan dan faktor apa saja yang dapat mendukung keberhasilan dari perusahaan melalui partisipasi dari masing masing bagian. Faktorfaktor keberhasilan dari masing masing bagian merupakan suatu fondasi dari apa yang ingin dicapai perusahaan secara keseluruhan.

Divisi IT (Information Technology) berperan dalam membantu masing masing bagian ini untuk mencapai keberhasilannya. Tidak semua CSF dari masing masing bagian ini dapat diintepretasikan ke dalam IT, contohnya adalah pelayanan yang ramah dari bagian Customer
Service. Ini merupakan suatu sikap/perilaku dan tidak dapat diterjemahkan ke dalam lingkungan IT. Ada 3 keluaran yang dihasilkan dari analisis terhadap perusahaan, yaitu target aplikasi prioritas (Gambar 4), target teknologi (Gambar 5), dan target sumber daya manusia (Gambar 6).

Sedangkansaranyangbisadiberikanterhadappenelitian ini, yaitu (1) Untuk mendapatkan hasil yang lebih akurat dalam merencanakan IT Strategic Planning, analisis terhadap semua departemen secara keseluruhan akan menghasilkan IT Strategic Planning yang lebih detail dan lebih utuh; (2) IT Strategic Planning dapat berubah seiring dengan kebutuhan bisnis dan lingkungan IT, perkembangan lingkungan bisnis di antaranya adalah faktor keuangan. Persaingan dengan kompetitor lain mempunyai peranan yang cukup signifikan dalam perubahan IT Strategic Planning. Demikian juga dengan perkembangan dunia IT itu sendiri yang sedemikian cepat mengalami perubahan, dari segi teknologi terutama. Revisi dan monitoring terhadap IT Strategic Planning yang ada sangat dianjurkan, terutama pada tahap implementasi serta pemilihan supplier dan jadwal; (3) Implementasi yang baik, ditunjang dengan adanya manajemen yang baik untuk memastikan keberhasilan yang dikehendaki; (4) Perubahan struktur organisasi pada divisi IT, di mana diciptakannya IT Country Manager sehingga mempunyai level/posisi yang sama dengan bagian lain sehingga dapat 'diperhitungkan' dalam penentuan bisnis dari perusahaan; (5) Aplikasi Balance Score Card diimplementasikan sebagai indikator dari masing masing aplikasi yang telah dikemukakan sebelumnya sehingga dapat diketahui pada sisi yang mana dari BSC telah dicapai dan yang mana yang belum dicapai.

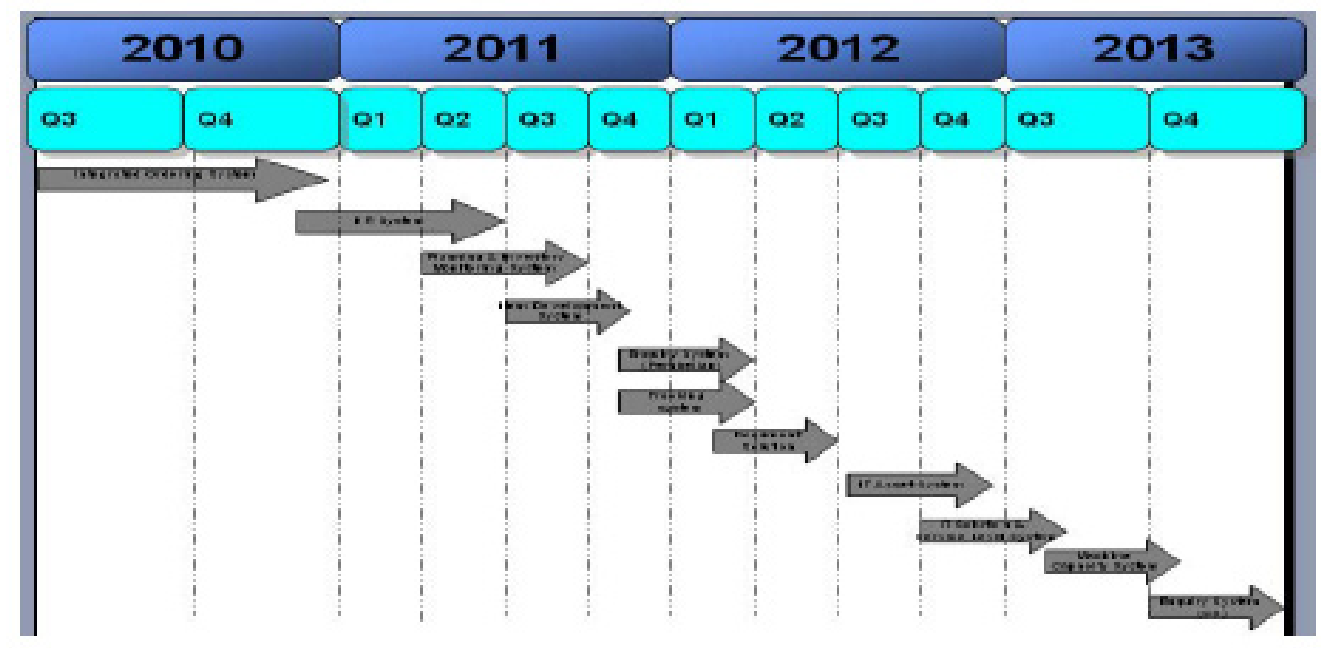

Gambar 4 Target Aplikasi Prioritas

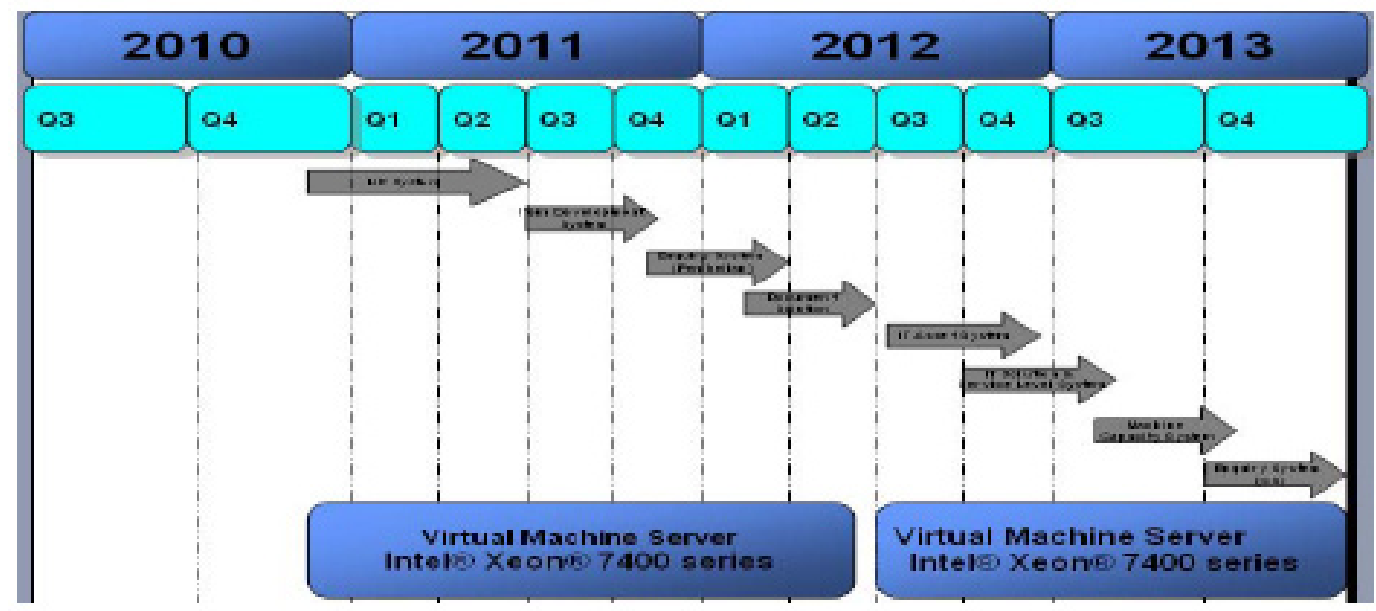

Gambar 5 Target Teknologi 


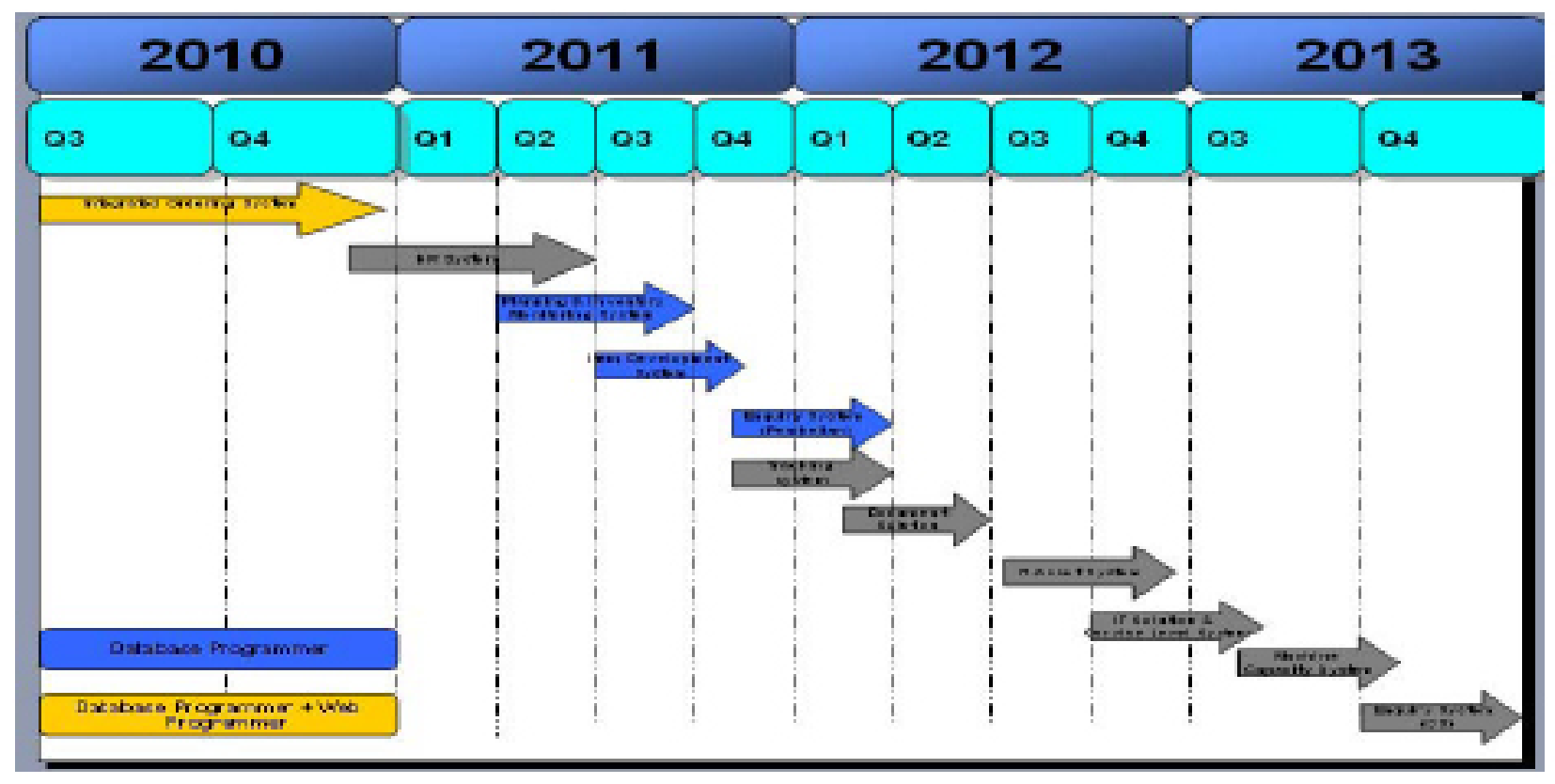

Gambar 6 Target Sumber Daya Manusia

\section{DAFTAR PUSTAKA}

Betz, F. (2001). Executive strategy: Strategic management and information technology, New Jersey: John Wiley \& Sons, Inc.

Boar, B.H. (2001). The art of strategic planning for information technology, $2^{\text {nd }}$ ed., New Jersey: John Wiley \& Sons, Inc.

Buchta, D., Eul, M., and Schulte-Croonenberg, H. (2007). Strategic IT management: Increase value, control performance, reduce costs, $2^{\text {nd }}$ ed., Gabler.

Cassidy, A. (2006). Information systems strategic planning, $2^{\text {nd }}$ ed., Auerbach Publications.

Kwan Tan, A.W., and Theodorou, P. (2009). Strategic information technology and portfolio management.

Olsen, E. (2007). Strategic planning for dummies, Wiley Publishing, inc.

Porter, M. (Nov-Dec 1996). What is strategy?. Harvard Business Review. Retrieved from http://home.att.net/ nickols/strategy definition.html.

Stenzel, J. (2007). CIO best practices: Enabling strategic value with information technology, Hoboken, New Jersey: John Wiley \& Sons, Inc.

Ward, J., and Peppard, J. (2002), Strategic planning for information systems, $3^{\text {rd }}$ ed., New Jersey: John Wiley \& Sons, Ltd.

Webster, B.F. (2008). Buy versus build software applications: The eternal dilemma. Retrieved from http://www.baselinemag. com/c/a/Application-Development/Buy-vs-Build-SoftwareApplications-The-Eternal-Dilemma/. 